\title{
Academia in the Fast Lane vs. Organisational Ethnography and the Logic of Slow Food
}

\author{
Harry Wels
}

\begin{abstract}
The chapter entails a reflexive, autoethnographic approach to think through some of the perceived developments in global academia, especially in terms of time and workload in the light of demands of academia, past and present. The author takes empirical data and substantiations from his own teaching experiences in the Netherlands and frames a cautious hope for a future of academia on the metaphor of the slow-food movement which was started in Italy in the mid-1980s.
\end{abstract}

\section{Keywords}

slow science - academic teaching - work pressure - freedom

Every book is a form of quiet gratitude - to the ideas, people, and encounters that formed it.

DONSKIS, 2013, p. 94

\section{Introduction}

Working in academia is by many staff members perceived as a 'rat race'1,2 resulting in perceptions of overload and work pressure (for the Netherlands,

1 www.huffingtonpost.com/vicki-abeles/education-stress_b_5341256.html, accessed 28 October 2016.

2 http://theconversation.com/cracks-in-the-ivory-tower-is-academias-culture-sustainable -8294 , accessed 28 October 2016. 
see $\mathrm{FNV}, 2017^{3}$ ), indicating that it is all about how fast one can get students through a curriculum and how fast one can publish and 'show results' in career competition with others. These are all aspects of the corporatisation of the university (cf. Reading, 1996; Ginsberg, 2011). The question is whether this is a 'bad' thing for the academic project (see for a balanced analysis of what slow and fast means for issues of inequality and power, Martell, 2014), or more specifically, for critical intellectual growth and development, which is arguably the driving goal or project of the academy (cf. Moshman, 2003)? In other words, is this kind of acceleration in academia something to be worried about or should we actually allow for a 'temporal autonomy' (Vostal, 2016) of academia, that is, everybody decides for her or himself? In this chapter I will argue that in a generalised way, intellectual development needs time to mature and therefore this acceleration is threatening the academic project to say the least, if not destroying it completely. I will argue metaphorically that like 'fast food', 'fast academia' is not intellectually healthy, no matter how tasty it might be considered at first bite (cf. Berg \& Seeber, 2016; Mountz et al., 2015). I take organisational ethnography as my example and metaphor for 'slow science', as that is the research I have been involved in throughout my own academic life. I further take inspiration from the slow food movement as others have done, with the proverbial snail as its logo (ibid.).

The slow food movement started in 2009 in Italy and its symbol became the snail. ${ }^{4}$ The movement started as a contestation of the junk and fast food industry. It has been actually part of a worldwide movement of slow, ${ }^{5}$ actually rather fast, in which 'slow' has also been applied to other spheres of life like parenting, reading, and sex (Honoré, 2004). Bauman and Donskis (2013) use the logic of the slow food movement as a metaphor for what ordinary life in academia should be, a logic 'of deliberate thought, unhurried creativity, and measured existence' (Bauman \& Donskis, 2013, p. 136, italics added); they make a plea for universities to be facilitators of 'intellectual slow food' (ibid., p. 137). 'Slow', not in the sense of dull, stodgy, dispassionate, or apathetic, all words belonging to the same family of 'slow', but rather living up to the example of that other animal that reminds us of slow, the turtle. '(I)n Native American lore, turtles remind us of the pace at which natures grows. Seedlings don't turn into trees

3 Some selected results from this report to substantiate the claim of 'work pressure' among academic staff (in the Netherlands): $66 \%$ of the 2546 respondents say that they can never finish their work; $78 \%$ structurally work during weekends and evenings; $53 \%$ work during holidays; $45 \%$ continue to work during illness.

4 www.slowfood.com/about-us/our-philosophy/, accessed 23 June 2016.

5 www.slowfood.com/about-us/our-philosophy/ -'slow food world-wide'. 
in a week. Sod only becomes grass after months of tending. Damaged nerves don't recover, sometimes, for months. ${ }^{6}$ Intellectual development could be added to these examples that need time to mature, 'marinate', to stay close to the discourse of the slow food movement, and become full grown and growing. But instead, in their argument, universities have become and follow 'a logic of quick results and achievements' (Bauman \& Donskis, 2013, p. 136), a university with an intellectualism that opens the doors to a 'consuming university' (the title of the chapter, 131-167); universities have chosen the fast lane.

In Michael Foley's (2012) wonderfully entertaining but at the same time beautifully reflexive book on 'the ordinary' and the lessons we could take from 'the [literary] champions of everyday life' like Marcel Proust, James Joyce, and the like, he describes how Western culture has embraced a quantitative approach to time 'in units extending forward and backward' (Foley, 2012, p. 137), instead of an approach that takes into account how we experience time, which is not through measuring it but through 'feeling' (p. 137) it as a process. A maybe surprising but I think relevant example of this 'feeling' in the context of (organisational) ethnographic fieldwork in relation to time, and one that we can probably all relate to at some stage, is boredom. '(F)or the bored person, time seems to stand still', while 'for a person totally absorbed... time almost ceases' (Raposa in Toohey, 2011, p. 20). In boredom one has to wait for time to pass, it 'is never an easy emotion to tolerate', but at the same time boredom 'has always had this curious connection with creativity' and it allows 'you to be yourself' (Toohey, 2011, p. 186, italics added). In ethnographic fieldwork, or 'Deep Hanging Out' as Clifford Geertz (1998) translated and coined the term, in whatever contexts, there are always and inevitably times of boredom (I can attest to that after 30 years of fieldwork experiences). 'Boredom and lethargy are often experienced by ethnographers in the field but much less written about. Ethnographers are prone to write about moments of action. As a result, they often give the impression of their fieldwork as a series of exiting events. In most fieldwork there is indeed conflict, joking, and activity. Nonetheless, much of what many witness in their field research is low-energy, slow and, quite frankly, boring.7 And in the context of 'slow' we need that boredom like nothing else, as Kets de Vries (2014, p. 2) observes: 'I suggest that doing nothing and being bored can be

6 www.psychologytoday.com/blog/is-no-fairy-tale/201111/why-slow-is-good-lessons-turtle, accessed 28 October 2016.

7 http://aissr.uva.nl/research/externally-funded-projects/sites/contentı//ethnography27-29-august/sessions/sessions.html\#anker-f-boredom-and-lethargy-in-ethnography-mar guerite-van-den-berg, accessed 28 October 2016. 
invaluable to the creative process. In our present networked society, introspection and reflection have become lost arts (...) (D)oing nothing is a great way to induce states of mind that nurture our imagination (...) Seemingly inactive states of mind can be an incubation period for future bursts of creativity (...) (U)nconscious thought processes can generate novel ideas and solutions more effectively than a conscious focus on problem solving'.

This boredom though has not only got to do with time but also with the content of ethnographic fieldwork. Ethnography, and organisational ethnography for that matter, focuses on the everyday of ordinary life (Ybema et al., 2009). Ethnography is considered a methodological approach (O'Reilly, 2012), a practice (Pink, 2009), an interpretive assemblage (Yanow \& Schwartz-Shea, 2015), a writing skill (Clifford \& Marcus, 1986), that asks for a combination of a particular form of boredom with the mundane, the banal, the unimaginative on the one hand and intellectual creativity to make analytical sense of it on the other. 'Doing ethnography' according to Geertz (1973) refers to 'fieldwork' and 'being there' (Watson, 1999; Borneman \& Hammoudi, 2009), but at the same time to the writing of the ethnography (Brettell, 1993). Boredom is a quintessential aspect of 'doing ethnography', both in the field and in writing. Fieldwork and writing in ethnography should not be seen as two different consecutive phases in the process of doing ethnography, but as two aspects of the same process, 'doing ethnography', in which there is writing during fieldwork (of field notes, reflexive notes, diaries, and capturing everyday life) and fieldwork in the writing (reliving, interpreting, reflecting, and returning to the fieldwork (notes) time and again). Boredom is integral to this process as doing ethnography requires of the researcher to wait for things to happen, or not, which latter can be just as significant, in the field and behind the computer; time stands still and the ethnographer waits, anticipates, but is not the initiating agent of the everyday life that $\mathrm{s} / \mathrm{he}$ is trying to grasp, capture and understand. $\mathrm{S} / \mathrm{he}$ is also not waiting for spectacular things to happen but to experience the 'boring' routines of the everyday in organisational life; things that hardly anyone notices as they are so common and familiar, that for anyone else belong in and dissolve into the uninteresting and boring background of organisational life. Like a monotonous noise that you forget about, don't hear any longer, until it stops, and then you realise that is was there all along, but it had become so familiar that it did not require any special attention anymore: it ceased to remain explicit. It is the creativity of the organisational ethnographer to interpret boredom and 'make (...) the familiar strange' (Ybema \& Kamsteeg, 2009, pp. 101-119), to make the monotonous explicit, to bring the background to life, to describe and analyse how the unconscious everyday shapes and directs organisational life as we know it; to make boredom exciting. 
Organisational ethnography is a process of the longue durée, a slow science. Not only because once you (dare to) label yourself as an ethnographer after so many years of experience in fieldwork, it also takes a long process to learn and acquire the skills that an ethnographer needs: 'doing ethnography' requires a pedagogy that 'takes time' and sees time as an ally instead of as an opponent that has to be conquered and beaten, time that marinates and matures 'doing ethnography', like in slow food (therefore the word 'marinate' seems so appropriate). In what the university has become there seems no room left for this pedagogy that embraces and cherishes time, that asks of students and researchers alike to immerse themselves for a longer period of time in the field and the everyday at home or abroad, that asks for craftsmanship and a guild-like set up of apprenticeship, a pedagogy that gives and allows for time instead of taking it by clocking and measuring only research outputs: 'how will we form the next generation of European intellectual and politicians if young people will never have an opportunity to experience what a non-vulgar, nonpragmatic, non-instrumentalised university is like' (Bauman \& Donskis, 2013, p. 139).

In this chapter I present a personal case study of how students struggle with organisational ethnography as a topic, standing for all the slow sciences, in the current 'corporatisation of academia' (Alvesson, 2013b). I will do that in a style that will use a combination of Bauman and Donskis' book (2013) and Geppert and Hollinshead article (2017) as its example, respectively as a (heated) conversation - between me and the readership of this book - and basing myself on my own subjective experiences in mainly Dutch, and to a lesser extent South African, ${ }^{8}$ higher education. All this takes place in a context that I sometimes experience as coming close to what Geppert and Hollinshead $(2017$, p. 9) write that 'the bottom line is sustained by the spreading of the belief that no employee is good enough, no venture is good enough and no action is good enough. This has resulted in this essay, which has some characteristics of a lampoon in its positioning vis-à-vis what the university, also thanks to me, ${ }^{9}$ may have become.

8 My research has been located in South and southern Africa since the mid-1980s, with an emphasis on South Africa since the second half of the 1990s. All this research and the ensuing publications are very much part of my intellectual development over the years and shine through strongly in my professional identity.

9 Please don't get me wrong, I am no saint and I have been part and parcel of this process that I now critique: 'the dismantling was accomplished with our own hands, the hands of academics... We are all accomplices in that accomplishment: even those few among us who felt like protesting and never gathered the courage and determination to stop the rot' (Bauman \& Donskis, 2013, p. 140). 
After many years teaching in an international Master's programme, I am asked to give a course on organisational culture and ethnography for second year Bachelor's students. This course has never been a problematic one for students at all, most of them usually pass. The course has a very basic structure: 13 lectures, including a final Question and Answer session, 115 minutes each. I prescribe two books, one of 236 pages from cover to cover, including content pages, bibliography, and index, and a second one 337 pages long. The first book (Alvesson, 2013a) is a theoretical one trying to argue for a particular approach to understanding organisational culture and change: a book in its second edition, with two new additional chapters. The second one (Jansen, 2009) is an organisational ethnography of a cultural change process at a South African organisation. The first one has been used in this course before (but in a first edition); the second one is new.

The lectures take the students through all the chapters, and for pedagogical reasons made explicit and elaborated upon during the opening lecture, without the use of Power Point and also not providing summaries of the books. The teaching is very much in the spirit of a 'reflexive pedagogy' (cf. Harling Stalker \& Pridmore, 2009): contextualising the two books intellectually and ethnographically and trying to challenge students to reflect on their own positionality in relation to the two books and the social and cultural realities these two books try to represent and understand. During every lecture I tell them about the exam at the end of the course and give them one or two questions that I could ask in the exam. I tell them that everybody can pass the exam as I will ask them to reproduce the academic texts that are discussed during the lectures for some $60-70 \%$ of the questions and $30-40 \%$ of the questions will be about interpretation of the texts. At the end of the course I have given the students at least some 13-15 examples of possible exam questions (which I did not ask in the actual exam, as I told them).

Originally 310 students registered for this course (registration list at Study Secretariat). The university bookshop sold 74 copies of the more theoretical book of Mats Alvesson, which is now a second edition with two added chapters compared to the first edition, and 103 copies of the organisational ethnography of Jonathan Jansen (personal communication with the university bookshop). During the lectures I always combine chapters of the two books so as to mix and juxtapose the more theoretical understanding of organisational culture and change with the more ethnographic and empirically orientated case study from South Africa. The people from the bookshop tell me that they 
ordered extra copies of the organisational ethnography twice, as they were 'overwhelmed' by the number of copies sold, still, sales by far do not exceed half of the number of registered students.

There are two lectures a week, one on Tuesdays from 9 am till 10:45 am and a second one on Thursdays, from 1:30 pm till 2:45 pm. The lecture halls are big enough to host all 310 students. The opening lecture is attended by an (optimistically) estimated 100-120 students. From the second lecture onward attendance drops to between $45^{-65}$ students. The lecture on Tuesday attracts the smallest number of students. The ones that come to all the lectures I start to recognise and know by name, and I enjoy giving the lectures and the interaction with these 'hard core' students.

Towards the end of the lectures and the course, I receive from the administration the list of students that have registered for the exam, 298. Because of the large number there are quite some logistics involved and the exam is held in a convention centre in Amsterdam in order to be able to host that many exam students (together with other exams from other faculties of our university). Furthermore, because of the large numbers I only deliver the right number of exams and paper to write on and for the rest the logistics around and during the exam are taken care of by people from an employment agency. It is appreciated if you, as lecturer, show your face at the beginning of the exam, which I do. I recognise the regular attendees of the lectures and wish them well. I see more people though that I have never seen before, but whom I equally wish good luck with their exam. It results in a $31 \%$ pass rate (Study secretariat).

The resit of the exam (second and last opportunity) is a couple of weeks later and 166 students register for this second attempt. After some five to seven emails from students requesting an extra Q\&A session before the resit, I organise what they ask for. I prepare myself well and organise three sub-sessions of half an hour based on the first letter of their surnames (A-H, I-P, Q-Z) in order to give every student that comes the attention he or she deserves. I post all this information on Black Board and every student receives an individual email with this information. At the actual session, eight students show up. The resit has a pass rate of $23 \%$ (personal communication with the Study secretariat). I anticipate protests as now all the students that have failed have to take the exam next year. I receive some three emails, but that is it. One of them asking if I will use the same literature next year. From the answers to the exam questions, I can clearly notice that many students just haven't read the books at all.

This is what happened during the academic year 2015-2016 (and repeated itself in 2016-2017 and 2017-2018). The coordinator of this Bachelor's programme has asked me if I am prepared to give the course again next year, which I happily agreed to. The evaluation of the course is filled in by 72 students and is 
very positive about my enthusiasm during lectures, but rates the exam as suboptimal. The scores for these items were below average, especially on the items 18 , 19, and 23 , respectively asking to rate: 'I knew clearly in advance what to expect in the exam; the exam was a good indicator of what I had learned in this course; overall rating of the exam'. Actually, and ironically, the very items for the evaluation reproduce the arguments I try to raise below! On the whole, the graph of the evaluation showed that this course was below the average university score, except for that one item out of 20, 'encouraged to think about the material', which scored way above average (this was not only mimicked in 2016-2017 and 2017-2018 but also led to an even more devastating graph below the average university score).

Similar stories come to me from colleagues from other Dutch universities and from other disciplines, and also internationally. I hear similar stories, but usually only informally and after a drink or two, which is of course 'subjective' and cannot be taken into consideration as it is not 'official' and 'too ordinary and everyday'. But ethnographic fieldworkers know better than to just shuffle this information aside as 'irrelevant'.

It seems clear that at least part of what might be happening here is that taking time to read and study is under severe threat for students. I would like to take that observation up later in the chapter but first want to flag and briefly mention that in this personal example a lot of critical issues with regard to what is happening in higher education around the world seems to come together. First of all, the McDonaldisation and massification of higher education (Parker \& Jary, 1995; Altbach et al., 2009; Rossi, 2010), which implies that students in academia are treated like particles in a process of industrial rationalisation and commodification. Its flipside is that students start to behave like consumers in a restaurant and leave what they don't like and generally behave like 'clients with demands' (cf. Hayes \& Wynyard, 2006). ${ }^{10}$ The rationalisation of universities as 'businesses' furthermore encourages students to see academia more as an extension of their earlier primary and secondary school experiences than as institutions that foster independent and critical thinking. It seems that as a result we should conclude that critical thinking is on the decrease. ${ }^{11}$ Important to note here, also to come back to taking (slow) time to read (and study), is the observation that ' $(\mathrm{t}$ )here is a necessary connection between critical thinking and skilled reading and writing' and 'if I know that

10 See also: http://time.com/108311/how-american-universities-are-ripping-off-youreducation/, accessed 28 October 2016.

11 www.criticalthinking.org/pages/the-state-of-critical-thinking-today/523, accessed 28 October 2016. 
what I am reading is difficult for me to understand, I intentionally slow down. ${ }^{12}$ Which brings us back to the question I would like to raise in the context of my argument in this chapter: What has (students') reading to do with the logic of slow food?

\section{Reading as Waiting}

A stereotypical story that is often told by Europeans that have visited the African continent is that 'Europeans may have the clock, but Africans have the time'. One could interpret this as that Europeans know how to measure time, but have lost touch with experiencing time. ${ }^{13}$ It is a common complaint in our global societies that we don't find time to read anymore. ${ }^{14}$ If we are to believe what people say, they would love to read more, but they simply don't find or have time for it. The paradox is the following: When we measure time, we can't find it to read books; when we read books, we experience time and find it. This counts for literature and popular books, and it also counts for ethnographies: when we try to find measured time, that is, the clock, to read a voluminous (organisational) ethnography we will never read it; if we read an (organisational) ethnography we will experience time and we will find the time to read. The logic of the slow food movement can be recognised here: If we constrict food in our clock driven existence, we will end up with fast food; if we experience time, we will end up as adherents of the movement and apply it metaphorically to our way of life, including our reading habits. That is to say, reading and allowing ourselves to experience time in the process, reading and requiring students to read books for their courses can become a conscious act of resistance to the further McDonaldisation of higher education.

But in our factory-like approach to higher education (cf. Parker \& Jary, 1995), reading books is probably considered as inefficient a suggestion as writing books in the Dutch context. Nowadays Dutch academics are pressured to write articles for 'high impact' journals and not devote time to writing books.

\footnotetext{
12 Ibid., emphasis added.

13 Disclaimer: This is not in any way meant to essentialise differences between 'European' and 'African' perceptions of time, so often rhetorically used to rationalise European power and privilege and legitimise racism.

14 See for instance: https://medium.com/@hughmcguire/why-can-t-we-read-anymore-503c $38 \mathrm{c} 31$ fe\#.5khrm16mc; https://www.theguardian.com/commentisfree/2014/oct/29/lovereading-dont-have-time-stop-excuses; http://www.forbes.com/sites/jordanshapiro/2014 /05/13/kids-dont-read-books-because-parents-dont-read-books/\#67c334334faa, all accessed 18 August 2016.
} 
In annual reviews it is literally easier to score credit points with journal articles than with publishing a book. If you speak to academics informally during their ordinary everyday life, they might tell you that they do not even find time to keep up with the new journal articles that appear in their field, let alone books. Often, they tell you with a certain sense of pride and professionalism that their phone has 'an app' that 'alerts' them to new articles in their field with a title or an abstract. Because of the numbers of journal articles being published, they admit that they usually do not proceed beyond the alert but still consider themselves on top of their discipline by just being alerted to new articles without ever reading them in full. Maybe there are colleagues who will officially challenge this gross generalisation, but my combination of 'auto-ethnography' (Ellis, 2004) and 'at-home ethnography' (Alvesson, 2009) can substantiate this claim with countless anecdotes, examples, and other (organisational) ethnographic details that I have taken from my everyday academic life for more than 25 years.

Part of intellectual slow food is slow reading, ${ }^{15}$ for which there is no longer sufficient time in academia. Together with the increasing pressures to write and publish articles (often replacing books) is the lack of time and patience to read texts from start to finish or from cover to cover. It should be noted of course that because all academics are so pressured to publish articles, the tsunami of articles that are actually published is staggering and there is no way that anyone can ever read them all, or even keep up with new literatures, let alone to intellectually reflect on the contents. This occurs all the more so in a context in which academic credibility and status is measured in numbers of article citations and not in the numbers of pages, articles, and books you read, nor the possible impact of reading contents and combinations of thought.

Experiences and examples from another angle: Facilitating Post-Graduate Supervision ${ }^{16}$ courses in South Africa for many years, we agree time and again with our South African colleagues from various universities across the country, and from different disciplines, how reading is at the heart of building a

15 See www.slowmovement.com/slow_books.php (accessed 9 August 2016); www.slowbookmovement.com (accessed 9 August 2016). The 'slow book manifesto' argues that only particular books count as 'slow books': they insist on literature. 'Blog posts won't, of course, but neither will newspaper pieces or even magazine articles. Also excluded: non-literary books (www.theatlantic.com/entertainment/archive/2012/03/a-slow-booksmanifesto/254884/) (accessed (9 August 2016).

16 See for more information on this project: http://postgraduatesupervision.net/, accessed 31 May 2018. 
scholarly identity for post-graduate students. No matter the almost unanimous agreement on the importance of reading for developing a scholarly identity, when we talk as academic colleagues, staff members amongst ourselves, about our own (academic) reading behaviour, most of us have to admit that we hardly if ever read articles or books from beginning to end anymore ourselves. Many of us usually read efficiently what parts we need for our own writing and the quotes we want to use in our publications or what we have to read in terms of students' work, which usually leaves hardly any time to read anything else, let alone in full. This pressure to live up to this kind of academic efficiency and so-called 'professionalism' leaves nothing to chance; we cannot be surprised anymore by what we read. We know what we want for our own writing and how to judge students' work. Reading (academic texts) has become equally instrumentalised to our writing and protocolised in terms of our assessments of students' work; the fulfilment of reading is gone.

Let me make it personal and talk to you, my colleague, through the text of this essay: when were you last intellectually 'blown away' by an unexpected article or a book; when was it that you (nearly) forgot about yourself, and time for that matter, because you were so absorbed in the reading that you felt as if having entered a parallel universe; when has a book altered your 'course in life' or academic thinking again; when was it that you felt awkward that the final pages were in sight and you actually loathed the moment that you would have finished the reading; when was the last time that you were 'taken over' by a text; when last was reading sensational; when was not finishing the text not an option that crossed your mind?

No matter how fast you read, when you read complete texts, you enter the domain of 'slow'; in reading complete texts there is some sort of appreciation for 'fully' getting to know something instead of in fragments, and of giving opportunity to an author to present and convince you as a reader of their argument. 'Full(y)' is probably a better word to use in this context than 'complete': You can finish your quantity of food completely, but in the logic of slow food it is not about finishing quantities, but about food that is 'full' of taste, with a connotation of being 'rich' in satisfying a variety of taste buds. This is how a text should taste, 'full' and 'rich'; it is not about quantity, but about the sensation and experience of fulfilment (what is in a word). 'Fulfilment' leads to being able to tell about the experience, the texts, with confidence and conviction; fulfilment facilitates reproduction of texts and main arguments.

One of my observations during courses was that students find it increasingly problematic to 'reproduce' or 'learn' texts by heart. In the time-consuming world we live in, there is no way that you can read a text and be able to reproduce 
what you have read first time. Harkening back to my course on Organisational Culture and Ethnography I described above: from the very first lecture onward I told my students that $70 \%$ of the exam questions would consist of questions that asked of you to 'just' reproduce. Furthermore, I told them that in marking the exams, we would grant more points to those answers that stayed closest to the texts in the books. Students told me that university education shouldn't be about reproducing texts. I tried to counter this by saying that in every professional field you should be able to reproduce standard, although temporary, 'truths' of the discipline, and that in a face-to-face conversation with a fellowprofessional on a particular topic that relates to your expertise, you cannot constantly rely on or refer to Google (or any other digital search device). Fulfilment leads to the ability to reproduce, like a poet who is saturated with reading and composing words, can recite texts ad libitum. Reading to the full and again and again is something that is close to the ideals of the slow food movement: local, everyday (staple) and seasonal produce comes back again and again and year in year out and can be recognised, reproduced, and recited by every cook and connoisseur. ${ }^{17}$

'Slow' connotes strongly with waiting and patience. In reading it is waiting for a plot to unfold, an argument to develop, and patience to reach the climax of the argument, the results of the reasoning. Patience and waiting are key ingredients of liminality (Sutton et al., 2011, p. 30; Schweizer, 2008, p. 112), a concept initially coined by Van Gennep in 1909 but broadly popularised by the late anthropologist Victor Turner (1920-1983) (1967, pp. 93-111) to denote the middle phase of a ritual process, in which an individual undergoes a transition from the one stage, phase, or position, into another one. Classic examples being puberty rites amongst various ethnicities around the world where females go into the first phase as girls and exit in the third phase as women. Or males go in as boys and exit as men. In the middle second phase 'individuals are understood to be "no longer" and simultaneously also "not yet"' (Wels et al., 2011, p. 1). In Turner's own words, 'neither here nor there; they are betwixt and between the positions assigned and arrayed by law, custom, convention, and ceremonial' (Turner 1969, p. 95); people (im)patiently await series of Deleuzian becomings. This is what reading and time is all about; it is a liminal phase of becomings, a liminal phase in which the reader awaits what next intellectual becomings will befall him or her. To read asks for patience, but it

17 This is not to say that 'truths' are once and for all or cast in stone. On the contrary even, academic 'truths' change and meander over time and are always in processes of Deleuzean 'becomings'. 
also develops patience in therapeutic ways; ${ }^{18}$ reading is an antidote to instantaneous living as seems to be propagated by the current time and age, and which the corporate university has embraced as its mantra. Diplomas must be produced in no time. This no longer allows for the creativity that experiencing time and a sense of boredom seems to generate. Reading as 'a temporary liberation from the economics of time-is-money, as a brief respite from the haste of modern life, as a meditative temporal space in which one might have unexpected intuitions and fortuitous insights' (Schweizer, 2008, p. 2) does not fit academic life or thinking any more. In the current time and age there is no time for waiting in academia, which paradoxically has led to a certain level of indifference, a lack of attention in the way that the French activist and philosopher Simone Weil spoke about it, when she suggested that waiting 'must be relearned as a form of attention' (in ibid., p. 2). 'Attention waits' (Blanchot in ibid., p. 89). Then waiting through reading 'can be a rewarding experience' indeed (ibid., p. 126) and lead to intellectual creativity.

Students, at least the ones that followed my second year Bachelor's course on Organisational Culture and Ethnography (OC\&E), based on the figures on the number of books being bought and by the number of students who passed two exams primarily geared towards checking how well the two books were read and could be reproduced as a result, seemed to have no time or patience to take this time to read or to wait and enter the liminal phase that is crucial to intellectual becomings. Might it have to do with the sense that students, fellow academics, and other people worldwide often complain or have a stereotyped idea that academic texts are 'boring'? 19 And boring in a way that they do not suspect that this could lead to creativity (see above)? I can see the point that academics write boring texts. I read them myself sometimes as well. But in organisational ethnography, in 'doing ethnography', writing in an attractive way is considered as important as the presentation of the data and its analysis. The best organisational ethnographies are sometimes real 'page turners'. Read Timothy Pachirat's (2011) Every Twelve Seconds about organisational processes in slaughterhouses in the United States, and I promise you, you will not stop reading before the book is finished. There are more organisational ethnographies like that, one of them being one of the two books I prescribed for

18 https://www.daveursillo.com/7-unconventional-ways-to-develop-patience/, accessed 11 August 2016.

19 www.theguardian.com/education/2007/sep/04/highereducation.news. Response: http:// onewaystreet.typepad.com/one_way_street/2007/og/academic-writin.html. https:// pathsonwater.com/2015/03/25/dear-authors-why-are-academic-texts-so-boring/, all accessed 11 August 2016. 
my course OC\&E, Jonathan Jansen's (2009) moving account of eight years of having been the first-ever black dean of the Faculty of Education at the University of Pretoria: ${ }^{20}$ an organisational ethnography of which students asked me at some stage if it was 'really an academic text'. When I asked them what brought them to ask that question, they answered that they had to cry while reading it, and that this had, they tell me, never happened to them before with an academic text. Was reading Jansen's organisational ethnography worth the waiting? Was the imagined boredom of reading a book from cover to cover resulting in attention? I actually interpret my almost, if not completely, obsessive reading of books from cover to cover as one of my most explicit acts of resisting the cult of speed in academia, an 'ethical choice' (Berg \& Seeber, 2016, p. 59), where '(s)lowing down is about asserting the importance of contemplation, connectedness, fruition, and complexity' (ibid., p. 57). Shouldn't reading, in the spirit of the logic of the slow food movement, not be made more explicit as an integral part of 'doing ethnography' and doing scientific and intellectual work in general? Reading as an act of resistance to the 'rat race'?

Almost any reader will realise that the question with which I ended the previous section is strictly a rhetorical one, with only one answer possible, YES! When Brettell (1993) edited her book and referred in the title to 'read(ing)', she did not mean to say that reading should be part of 'doing ethnography'. She reflected on what happens if people read what has been written about their everyday lives: Do they recognise themselves in the text; do they agree with how their lives are represented by a (relative) outsider ethnographer. In other words, it is an edited volume on the politics of representation. This is the general trend in the debates, discussions, and conversations about 'doing ethnography', that the concept of reading is not contextualised and problematised enough in the literature on 'doing ethnography', is too much taken for granted, too much taken in the direction of the topic under research, and is not applied to the reading habits of the ethnographer him or herself. The kind of reading I have been trying to argue for in this essay is about the experience of reading (as related to time and fulfilment) and its beneficial effects on ethnographic creativity and intellectualism, and how this time-consuming activity of reading 'thick books', full of 'thick descriptions' (cf. Geertz, 1973) is worth the waiting and the effort. Or even more strongly put: to me slow reading is crucial for

20 The University of Pretoria is, in terms of the apartheid system of divided categorisations, a historically white and Afrikaans-speaking university. 
developing and sustaining a level of intellectualism that a university education in my perspective should offer to students and that should be the preferred habitus (cf. Bourdieu, 1984 ${ }^{21}$ ) of academic staff. Given the 'corporatisation of the university', the habitus that is 'guiding' (see definition in note 6o) academics now is 'the fast lane' as described and pointed out above. 'Doing (organisational) ethnography' in the way I argue for can be seen as a counter movement to this 'fast lane' habitus, while at the same time suggesting a concrete alternative habitus. The alternative habitus would then be to slow down and go slow on intellectual development, to go slow on reading, to go slow on writing, to go slow on the academic project as a whole; go slow in order to fast-track intellectual development and critical thinking; universities facilitating a habitus that takes 'doing ethnography' as its metaphor and example for 'slow science' following in the spoor and logic of the 'slow food' movement.

As this book is dedicated to the memory our dear Leonidas Donskis, I would like to end, as I started, with one of his inspiring aphorisms, although this time slightly adapted for reasons of fit: 'In death a friend extended my life - by redrafting the cartography of my thoughts and by becoming the subject of my [chapter]' (Donskis, 2013, p. 104). ${ }^{22}$

\section{References}

Altbach, Ph.G., Reisberg, L., \& Rumbley, L.E. (2009). Trends in global higher education: Tracking an academic revolution, A report prepared for the UNESCO 2009 World Conference on Higher Education, retrieved from https://s3.amazonaws .com/academia.edu.documents/30910755/Altbach__Reisberg__Rumbley _Tracking_an_Academic_Revolution__UNESCO_2009.pdf?AWSAccessKeyId $=$ AKIAIWOWYYGZ ${ }_{2} \mathrm{Y}_{53} \mathrm{UL}_{3} \mathrm{~A} \&$ Expires $=1527766860 \&$ Signature $=\mathrm{cse} \% 2$ BogfbYyKiZKgzJ6Dd\%2BosQ1vY\% ${ }_{3}$ D\&response-content-disposition=inline $\%{ }_{3} \mathrm{~B} \%$ 2ofilename\%3DTrends_in_global_higher_education_Tracki.pdf, (31 May 2018).

Alvesson, M. (2009). At-home ethnography: Struggling with closeness and closure. In Ybema, S., Yanow, D., Wels, H., \& Kamsteeg, F. (eds.) Organizational Ethnography. Studying the Complexities of Everyday Life (156-174). Los Angeles, London, Sage Publications.

21 Bourdieu's habitus is probably most clearly put by Wacquant (2005) (cited in Navarro, 2006, p. 16) as 'the way society becomes deposited in persons in the form of lasting dispositions, or trained capacities and structured propensities to think, feel and act in determinant ways, which then guide them' (http://www.powercube.net/other-forms-ofpower/bourdieu-and-habitus/, accessed 18 August 2016).

22 The exact citation is 'In death a friend extended my life - by redrafting the cartography of my thoughts and by becoming the subject of my new book' (italics added) 
Alvesson, M. (2013a). Understanding Organizational Culture. Los Angeles, London, Sage Publications, Second Edition.

Alvesson, M. (2013b). The Triumph of Emptiness. Consumption, Higher Education, and Work Organization. Oxford, Oxford University Press.

Bauman, Z., \& Donskis, L. (2013). Moral Blindness: The Loss of Sensitivity in Liquid Modernity. Cambridge, Polity Press.

Berg, M., \& Seeber, B.K. (2016). The Slow Professor. Challenging the Culture of Speed in the Academy. Toronto, University of Toronto Press.

Borneman, J., \& Hammoudi, A. (eds.) (2009). Being there. The Fieldwork Encounter and the Making of Truth. Berkeley, University of California Press.

Bourdieu, P. (1984). Distinction: A Social Critique of the Judgement of Taste. London, Routledge.

Brettell, C.B. (ed.) (1993). When They Read What We Write: The Politics of Ethnography. Westport, Bergin \& Garvey.

Clifford, J., \& Marcus, G.E. (1986). Writing Culture: The Poetics and Politics of Ethnography. Berkeley, University of California Press.

Donskis, L. (2013). A Small Map of Experience. Reflections \& Aphorisms (translated from Lithuanian by Karla Gruodis). Toronto, Berkeley, Guernica.

Ellis, C. (2004). The Ethnographic I. A Methodological Novel about Autoethnography. Walnut Creek, New York: Altamira Press.

FNV (2017). Rapport Werkdruk in Universiteiten, (Report on Work Pressure in Universities). Retrieved from www.fnv.nl/site/nieuws/webassistent/Annika -Heerekop/werkdruk-medewerkers-universiteiten-ongezond-hoog-3/onderzoek werkdrukuniversiteiten.pdf.

Foley, M. (2012). Embracing the Ordinary. Lessons from the Champions of Everyday Life. London, New York, Simon \& Schuster.

Geertz, C. (1998). Deep hanging out. The New York Review of Books, 45 (16), 69.

Geertz, C. (1973). The Interpretation of Cultures. New York, Basic Books.

Geppert, M., \& Hollinshead G. (2017). Signs of dystopia and demoralisation in global academia: Reflections on the precarious and destructive effects of the colonization of the Lebenswelt. Critical Perspectives on International Business, 13(2), $136-150$.

Ginsberg B. (2011). The Fall of Faculty: The Rise of The All-administrative University and Why It Matters. Oxford, Oxford University Press.

Harling Stalker, L.L., \& Pridmore, J. (2009). Reflexive pedagogy and the sociological imagination. Human Architecture, Journal of the Sociology of Self Knowledge, 7(III), $27-36$.

Haynes, D., \& Wynyard, R. (eds.) (2006). The McDonaldization of higher education. Charlotte, North Carolina, Information Age Publishers. 
Honoré, C. (2004). In Praise of Slow. How a Worldwide Movement is Challenging the Cult of Speed. London, Orion Books.

Jansen, J. (2009). Knowledge in The Blood. Confronting Race and The Apartheid Past. Stanford, Stanford University Press.

Kets de Vries, M. (2014). Doing nothing and nothing to do: The hidden value of empty time and boredom. (Faculty and Research Working Paper, INSEAD, 2014/37/EFE.). Retrieved from http://www.kı2accountability.org/resources/For-Parents/Hidden _Value_of_Empty_Time_INSEAD.pdf.

Martell, L. (2014). The slow university: Inequality, power, and alternatives. Forum: Qualitative Social Research, 15(3), art. 10.

Moshman, D. (2003). Intellectual freedom for intellectual development. Liberal Education, 89 (3), 30-37.

Mountz, A., Bonds, A., Mansfield, B., Loyd, J., Hyndman, J., Walton-Roberts, M., Basu, R., Whitson, R., Hawkins, R., Hamilton, T., \& Curran, W. (2015). For slow scholarship: A feminist politics of resistance through collective action in the neoliberal university. ACME: International Journal for Critical Geographies, 14(4), 1235-1259.

Navarro, Z. (2006). In search of a cultural interpretation of power: The contribution of Pierre Bourdieu. IDS Bulletin, 37(6), 11-22.

O’Reilly, K. (2012). Ethnographic Methods. London, Routledge, Second Edition.

Pachirat, T. (2011). Every Twelve Seconds. Industrialised Slaughter and The Politics of Sight. New Haven, London, Yale University Press.

Parker, M., \& Jary, D. (1995). The McUniversity: Organization, management and academic subjectivity. Organization, 2(2), 319-338.

Pink, S. (2009). Doing Sensory Ethnography. Los Angeles, London, Sage Publications.

Reading, B. (1996). The University in Ruins. Cambridge, Harvard University Press.

Rossie, F. (2010). Massification, competition and organizational diversity in higher education: Evidence from Italy. Studies in Higher Education, 35(3), 277-300.

Schweizer, H. (2008). On Waiting. London, Routledge.

Sutton, R., Vigneswaran, D., \& Wels, H. (2011). Waiting in ritual space: Migrants queuing for Home Affairs in South Africa. Anthropology Southern Africa, 34(1\&2), 30-37.

Toohey, P. (2011). Boredom. A Lively History. New Haven, London, Yale University Press.

Turner, V. (1967). The Forest of Symbols. Aspects of Ndembu Ritual. Ithaca, London, Cornell University Press.

Victor, T. (1969). The Ritual Process. Structure and Anti-structure. Chicago, Aldine.

Vostal, F. (2016). Accelerating Academia. The Changing Structure of Academic Time. London, Palgrave MacMillan.

Watson, C.W. (ed.) (1999). Being There: Fieldwork in Anthropology, Chicago, University of Chicago Press. 
Wels, H., Van der Waal, C., Spiegel, A., \& Kamsteeg, F. (2011). Victor Turner and liminality: An introduction. Anthropology Southern Africa, 34(1\&2), 1-4.

Yanow, D., \& Schwartz-Shea, P. (eds.) (2015). Interpretation and Method: Empirical Research and The Interpretive Turn. London, Routledge, Second Edition.

Ybema, S., \& Kamsteeg, F. (2009). Making the familiar strange: A case for disengaged organizational ethnography. In Ybema, S., Yanow, D., Wels, H., \& Kamsteeg, F. (eds.) (2009). Organizational Ethnography. Studying the Complexities of Everyday Life (101119). Los Angeles, London, Sage Publications.

Ybema, S., Yanow, D., Wels, H., \& Kamsteeg, F. (eds.) (2009). Organizational Ethnography. Studying the Complexities of Everyday Life. Los Angeles, London, Sage Publications. 